\title{
SERUM CHOLINESTERASE IN ANAESTHESIA WITH REFERENCE TO NEOSTIGMINE, FENTANYL, AND DIHYDROBENZPIRIDOL
}

\author{
J. W. R. MCINTYRE, F.F.A.R.C.S., AND D. J. CAMPBELL, PH.D.*
}

NEOSTIGMINE is used extensively to antagonize blockade of neuromuscular transmission produced by curare or gallamine. This effect is achieved by increasing the release of acetylcholine at the prejuctional site, by combining with the enzyme acetylcholinesterase at the neuromuscular junction, and probably also by direct action on skeletal muscle. Inhibition of serum cholinesterase (E.C. 3.1.1.8., pseudocholinesterase) also occurs, but this plays a very minor role in producing the effect for which neostigmine is usually administered. However, since this enzyme is related to the distribution of the drug within the body, it was of interest to measure the effect of neostigmine administered at the termination of surgery on genetically normal serum cholinesterase activity.

\section{METHOD}

Patients were premedicated with morphine or meperidine, atropine or scopolamine, and alternative anaesthetic techniques were applied. Both utilized a thiopentone succinylcholine induction, followed by curare to maintain muscular relaxation, and ventilation of approximately 50 per cent in excess of the Radford nomogram value. Anaesthesia was continued using halothane and nitrous oxide, or nitrous oxide and intermittent injections of fentanyl and droperidol. Blood samples were obtained as atraumatically as possible prior to induction, prior to administration of neostigmine, and ten and forty minutes later. Atropine $1.2 \mathrm{mg}$. was injected 2 minutes prior to neostigmine. All sampling took place between 7 A.M. and 2 P.M.

Serum cholinesterase was determined by the method of Kalow and Genest, ${ }^{1}$ using the substrate benzoylcholine chloride. The change in absorbance at $240 \mu$ when serum and substrate are incubated for 4 minutes at $30^{\circ} \mathrm{C}$. is a measure of cholinesterase activity. The normal range by this method is $80-150$ units.

\section{Results}

The changes in serum cholinesterase activity 10 minutes following neostigmine injection are shown in Figure 1. Figure 2 represents the return of cholinesterase activity 40 minutes after administration by relating the cholinesterase activity prior to drug administration to the cholinesterase activity 40 minutes later, expressed as a percentage of the original value. Table I gives details of the changes in enzyme activity that occurred during surgery, and Table II relates age to preinduction enzyme activity.

"Departments of Anaesthesia and Clinical Laboratory Services, University of Alberta Hospital, Edmonton, Alberta. 


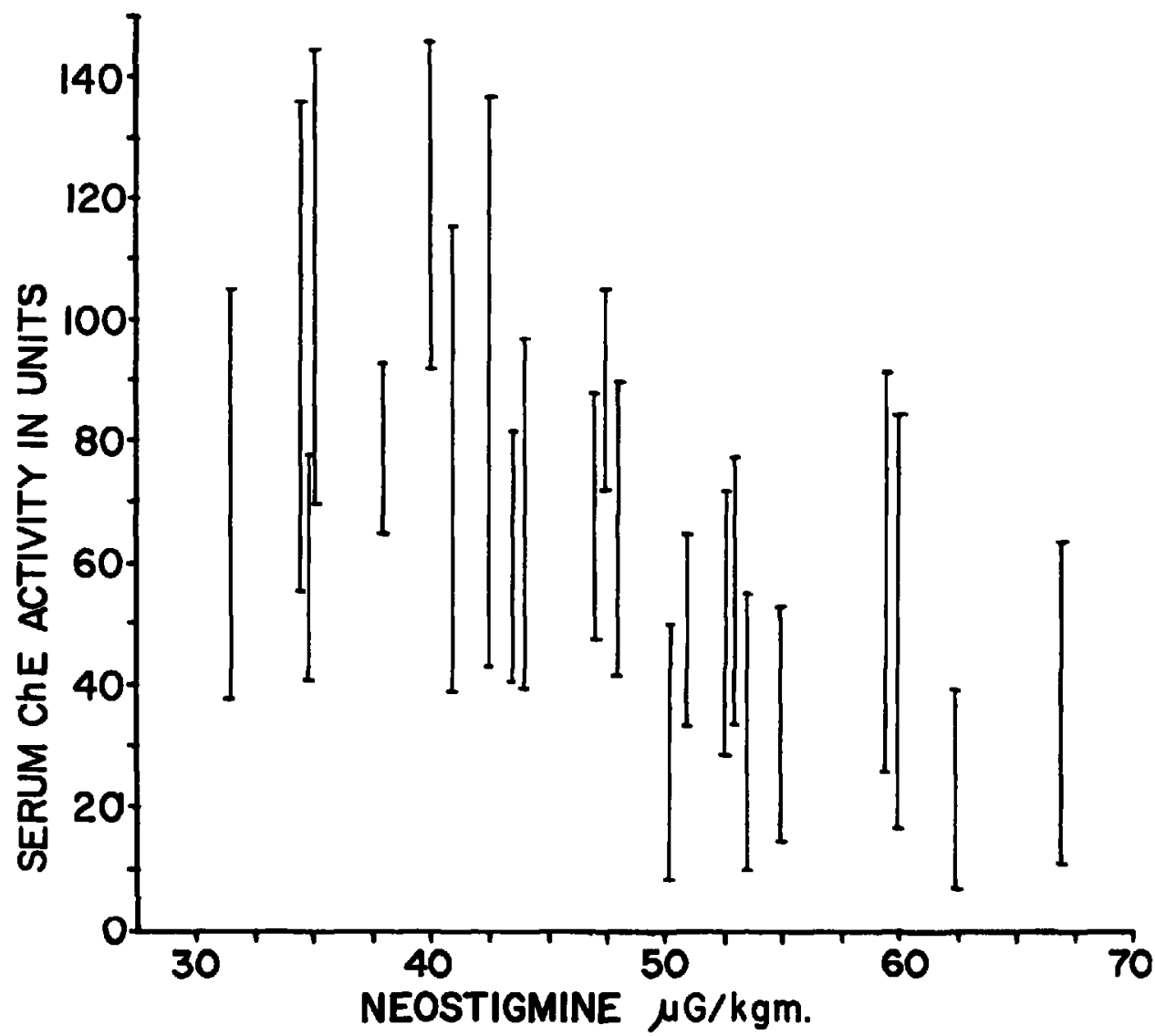

Frgure 1. Each vertical line represents the reduction in serum cholinesterase activity that had occurred in each patient ten minutes following neostigmine administration.

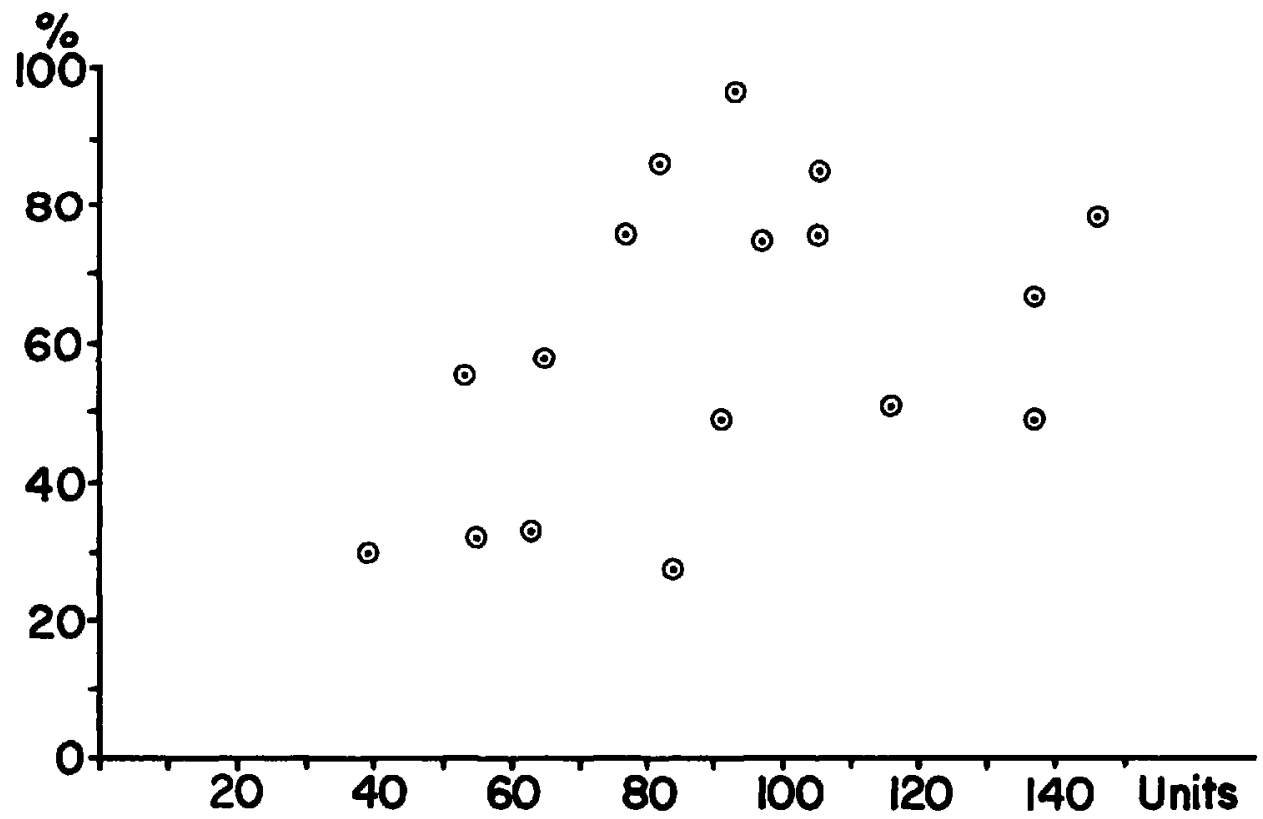

Frgure 2. Ordinate: Serum cholinesterase activity forty minutes after neostigmine administration expressed as percentage of activity prior to injection of drug. Abscissa: Serum cholinesterase activity prior to neostigmine administration. 
TABLE I

\begin{tabular}{|c|c|c|c|c|c|}
\hline $\begin{array}{l}\text { Serum Che. } \\
\text { activity at } \\
\text { induction }\end{array}$ & Surgery & $\begin{array}{l}\text { Dura- } \\
\text { tion } \\
\text { (min.) }\end{array}$ & Anaesthesia & $\begin{array}{l}\text { Blood } \\
\text { transfusion }\end{array}$ & $\begin{array}{l}\text { Che. } \\
\text { activity at } \\
\text { termination }\end{array}$ \\
\hline 100 & $\begin{array}{l}\text { abdominal perineal } \\
\text { resection }\end{array}$ & 165 & $\begin{array}{l}\text { thiopentone, } \mathrm{N}_{2} \mathrm{O} \text {, } \\
\text { fentanyl, droperidol, } \\
\text { curare }\end{array}$ & 1000 & 102 \\
\hline 101 & thoracotomy & 105 & " & - & 103 \\
\hline 39 & $\begin{array}{l}\text { Roux en } \mathrm{Y} \\
\text { anastomosis }\end{array}$ & 135 & $"$ & - & 50 \\
\hline 69 & pyloroplasty & 165 & $"$ & - & 75 \\
\hline 87 & $\begin{array}{l}\text { femoral popiteal } \\
\text { bypass }\end{array}$ & 205 & $" 1$ & 500 & 90 \\
\hline 106 & cholecystectomy & 155 & $"$ & - & 105 \\
\hline 101 & cholecystectomy & 160 & $"$ & - & 97 \\
\hline 99 & McMurray osteotomy & 105 & $"$ & 500 & 105 \\
\hline 79 & breast biopsy & 45 & $"$ & - & 84 \\
\hline 89 & $\begin{array}{l}\text { abdominal } \\
\text { hysterectomy }\end{array}$ & 95 & $" 1$ & - & 91 \\
\hline 67 & laparotomy & 95 & 11 & 200 & 77 \\
\hline 155 & spinal fusion & 140 & $"$ & 500 & 145 \\
\hline 41 & nephrectomy & 170 & $"$ & 2500 & 53 \\
\hline 132 & berniorrhaphy & 80 & $"$ & - & 116 \\
\hline 65 & portocaval shunt & 320 & $"$ & 2000 & 72 \\
\hline 65 & hip plating & 180 & " & 500 & 63 \\
\hline 68 & $\begin{array}{l}\text { repair detached } \\
\text { retina }\end{array}$ & 105 & $\begin{array}{l}\text { thiopentone, } \mathrm{N}_{2} \mathrm{O} \text {, } \\
\text { halothane, curare }\end{array}$ & - & 65 \\
\hline 63 & enucleation & 60 & " & $=$ & 55 \\
\hline 96 & gastrectomy & 210 & $"$ & 1500 & 82 \\
\hline 54 & cholecystectomy & 210 & $"$ & 1000 & 63 \\
\hline 39 & gastrectomy & 175 & $"$ & 500 & 39 \\
\hline 177 & gastrectomy & 145 & $"$ & - & 136 \\
\hline 88 & colectomy & 145 & $"$ & 500 & 93 \\
\hline
\end{tabular}

TABLE II

\begin{tabular}{cccc}
\hline $\begin{array}{c}\text { Age } \\
\text { (years) }\end{array}$ & $\begin{array}{c}\text { Serum } \\
\text { Che. } \\
\text { activity } \\
\text { (units) }\end{array}$ & $\begin{array}{c}\text { Age } \\
\text { (years) }\end{array}$ & $\begin{array}{c}\text { Serum } \\
\text { Che. } \\
\text { activity } \\
\text { (units) }\end{array}$ \\
\hline 50 & 41 & & \\
48 & 69 & 86 & 39 \\
45 & 132 & 85 & 39 \\
43 & 137 & 76 & 68 \\
40 & 67 & 75 & 87 \\
39 & 77 & 74 & 88 \\
34 & 177 & 73 & 54 \\
34 & 97 & 69 & 63 \\
33 & 89 & 67 & 100 \\
32 & 107 & 66 & 96 \\
29 & 101 & 64 & 99 \\
26 & 155 & 62 & 101 \\
24 & 65 & 58 & 111 \\
24 & 106 & 56 & 65 \\
21 & 79 & 54 & 72 \\
\hline
\end{tabular}




\section{Discussion}

It appears from the cases presented that neostigmine in clinical dosage can sometimes reduce cholinesterase activity to a low level. In common with all enzymes, serum cholinesterase activity reflects the presence or absence of inhibitors, activators, and cofactors. It is also well recognized that activity may be increased or decreased in a variety of clinical entities. Age and sex as factors affecting the enzyme have not been clearly elucidated. ${ }^{2,3} \mathrm{~A}$ variation with age is shown here (Table II), but other reasons for low values at induction have to be taken into consideration. These include liver dysfunction, macrocytic anaemia, and a variety of acute debilitating febrile diseases, as well as pregnancy and labour. ${ }^{4}$

Apart from drugs that have a direct depressant effect on liver function, a number of compounds have been shown to have an inhibitory effect on serum cholinesterase activity, including chlorpromazine $e^{5}$ and a variety of narcotic analgesics and their antagonists. ${ }^{6}$ The inhibitory effect of phospholine iodide eye drops has been described by Osserman, ${ }^{7}$ and clinical studies have been reported by other workers.8,9 The low preinduction level of the enzyme in one of our patients was associated with the use of this drug, and it is noteworthy that 150 minutes after the administration of neostigmine the enzyme activity was still only 47 per cent of the original value, which was 63 units.

The changes that occurred during surgery were small except in one case, and insufficient data is available for a definite explanation. Blood transfusions varying from 500 to $2,500 \mathrm{ml}$. played no apparent part in altering enzyme activity, and this agrees with the in vitro findings of Fromberg and his colleagues. ${ }^{10}$

Although the findings during general anaesthesia did not suggest that fentanyl and droperidol possessed a significant effect on the enzyme activity in vivo, the use of these drugs for sedative purposes during local anaesthesia encouraged confirmation of this hypothesis. Blood samples were taken from patients receiving no drugs other than fentanyl and droperidol, the results being shown in Table III. With the method described, there appeared to be no appreciable effect upon the enzyme activity.

Thus it seems that a low or subnormal serum cholinesterase activity may not be unusual in the surgical patient, particularly in the geriatric range, and a therapeutic dose of neostigmine can further reduce this activity. This occurrence might have a clinically significant effect on the quantity of any neostigmine administered subsequently that would be sufficient to produce depression of neuromuscular transmission, and on the inactivation of those drugs affected by this enzyme.

\section{SUMOMARX}

The activity of serum cholinesterase has been measured prior to and following surgery in patients anaesthetized with a nitrous oxide, fentanyl, droperidol, or halothane technique. Except in one case no significant changes occurred. Neostigmine reduced enzyme activity to a low level in some patients. This occurrence might have a clinically significant effect on the quantity of any neostigmine 
TABLE III

\begin{tabular}{|c|c|c|c|c|c|c|}
\hline $\begin{array}{c}\text { Age } \\
\text { (years) }\end{array}$ & $\begin{array}{c}\text { Weight } \\
(\mathrm{kg} .)\end{array}$ & $\begin{array}{l}\text { Serum } \\
\text { Che. } \\
\text { activity }\end{array}$ & Drugs & $\begin{array}{l}\text { Duration } \\
\text { of injection } \\
\text { (min.) }\end{array}$ & $\begin{array}{l}\text { Delay before } \\
\text { sampling } \\
\text { (min.) }\end{array}$ & $\begin{array}{l}\text { Pseudo-che. } \\
\text { activity }\end{array}$ \\
\hline 54 & 59 & 72 & $\begin{array}{l}\text { fentanyl } \\
\text { droperidol } 10 \mathrm{mg} \text {. }\end{array}$ & 4 & 3 & 77 \\
\hline 43 & 68 & 137 & $\begin{array}{l}\text { fentanyl } \\
\text { droperidol } 10 \mathrm{mg} \text {. }\end{array}$ & 4 & 3 & 130 \\
\hline 34 & 50 & 97 & $\begin{array}{l}\text { fentanyl } \\
\text { droperidol } 10 \mathrm{mg} \text {. }\end{array}$ & 4 & 3 & 103 \\
\hline 39 & 63 & 77 & droperidol $10 \mathrm{mg}$. & 4 & 3 & 76 \\
\hline 58 & 77 & 111 & $\begin{array}{l}\text { fentanyl } \\
\text { droperidol } 10 \mathrm{mg} .\end{array}$ & 4 & 3 & 106 \\
\hline 32 & 61 & 107 & droperidol $10 \mathrm{mg}$. & 4 & 3 & 106 \\
\hline 30 & 57 & 139 & droperidol $10 \mathrm{mg}$. & 4 & 3 & 137 \\
\hline 27 & 69 & 132 & droperidol $10 \mathrm{mg}$. & 4 & 3 & 134 \\
\hline
\end{tabular}

administered subsequently that would be sufficient to produce depression of neuromuscular transmission, and on the rate of inactivation of those drugs affected by this enzyme.

\section{RÉSUMÉ}

On a mesuré l'activité de la cholinestérase du sérum avant et après l'opération chez des malades anesthésiés au protoxyde d'azote, au fentanyl, au dropéridol ou à l'halothane. On n'a noté aucun changement sauf dans un cas. La néostigmine a diminué considérablement l'activité de cette enzyme chez quelques malades. Cette éventualité pourrait avoir un effet clinique important d'abord sur la dose de néostigmine qui serait administrée subséquemment et qui serait suffisante pour produire une dépression de la transmission neuromusculaire, puis sur le taux de diminution d'activité des médicaments influencés par cette enzyme.

\section{REFERENCES}

1. Kalow, W. \& Genest, K. A Method for the Detection of Atypical Forms of Human Serum Cholinesterase. Determination of Dibucaine Numbers. Can. J. Biochem. \& Physiol. 35: 339 (1957).

2. Gros, D. et al. The Administration of Di-isopropylfluorophosplate (DFP) to Man. Bull. Johns Hopkins Hosp. 81: 217 (1947).

3. Stranor, S. P. et al. The Intluence of Age and Sex on Human Plasma and Red Cell Cholinesterase. Amer. J. Med. Sci. 242: 357 (1961).

4. Sfnwmen, Sol M. Serum Cholinesternse Activity during Pregnancy and Labor. Anesthesiology. 26: 335 (1965).

5. Endos, E. G. et al. In Vitro Effect of Chlorpromazine on Human Cholinesterases. Fed. Proc. 15: 420 (1956).

6. Fordes, F. F. et al. Inhibition of Human Cholinesterases by Narcotics, Analgesics and Their Antagonists. Arch. Int. Pharmacodyn. 120: 286 (1959).

7. Osserman, K. E. et al. Proceedings of the Second International Myasthenia Symposium, Los Angeles (1959).

8. RoETrH, ANDrew DE. Effect of Phospholipine Iodide on Blood Cholinesterase Levels of Normal and Glaucoma Subjects. Am. J. Oph. 59: 586 (1965).

9. McGavi, D. D. MurRay. Depressed Levels of Serum Pseudocholinesterase with Ecothiophate-iodide Eye Drops. Lancet. 2: 272 (1965).

10. Frombera, H. F. et al. Succinylcholinesterase Activity in Stored Citrated Blood. Anesthesiology. $21: 64$ (1960). 